DOI: 10.15503/onis2014-43-47

\title{
IDEA OFIARY U EDITH STEIN
}

\author{
Agata Płazińska, agataplazinska@02.pl \\ Akademia Ignatianum w Krakowie \\ Ul. Mikołaja Kopernika 26, Kraków
}

(9) $(1) \Theta(\Theta$

\section{Abstrakt}

Autorka podejmuje próbę wykazania ważności ofiary, którą złożyła z siebie Edith Stein. Analizuje ten czyn za pomocą myśli ks. Józefa Tischnera i Emmanuela Levinasa; z punktu widzenia fenomenologii. Elementem spajającym jest biografia Edith Stein i łączące się z jej życiem liczne analogie z Pisma Świętego. Głównym punktem prezentowanego artykułu jest założenie, iż ofiara Edith Stein była wiodącą ideą jej życia.

Słowa kluczowe: Edith Stein, ofiara, filozofia, Józef Tischner, krzyż, fenomenologia.

\section{The idea of sacrifice at Edith Stein}

\section{Abstract}

The author attempts to demonstrate the validity of the sacrifice that Edith Stein made of herself, and analyzes the deed by thoughts of Józef Tischner and Emmanuel Levinas, from the point of view of phenomenology. The connecting element is the biography of Edith Stein and many analogies from Bible. The main point of the present article is the assumption that the victim Edith Stein was the most important idea of her life.

Keywords: Edith Stein, sacrifice, philosophy, Jozef Tischner, cross, phenomenology

Celem niniejszego artykułu będzie wykazanie, że wiodącą ideą życia Edith Stein była ofiara. Idea ta ujawniła się z całą mocą w drugiej jego połowie, odtąd zmierza ono coraz wyraźniej ku ofierze, którą złożyła za naród żydowski w gazowej komorze Auschwitz - jak Jezus Chrystus złożył ofiarę na krzyżu Golgoty. Ofiarę E. Stein zinterpretuję z pomocą myśli Emmanuela Levinasa i Józefa Tischnera.

\section{BIOGRAM}

Edith Stein, siostra Teresa Benedykta od Krzyża-niemiecka filozof, pochodzenia żydowskiego. Urodzona 12.10.1891 r. we Wrocławiu, śmierć w komorze gazowej w Auschwitz-Birkenau datuje się na około 9.08.1942 r. Wychowana w żydowskiej rodzinie z głębokimi tradycjami; po konwersji chrześcijanka - swoim życiem połączyła dwie religie w zwartą całość, pokazując, że chrześcijaństwo nie może odrzucać judaizmu. Dzieło jej życia rozpatrywać można w różnych aspektach: praw kobiet, dialogu religijnego i stosunków między narodami, tolerancji, a także literatury. Jawi nam się ona przede wszystkim jako wielkiego formatu filozof i teolog, która stawiała odważne pytania o sens ludzkiego życia i cierpienia. Analizując jej życie i twórczość możemy wyodrębnić trzy okresy:

1. gdzie jako ateistka koncentruje się wyłącznie na nauce,

2. szuka prawdy w oparciu o wiarę,

3. swoim życiem ukazuje świadectwo i ofiarę złożoną w imieniu krzyża.

W swoim artykule największą uwagę zwrócę na ostatni okres życia E. Stein, ponieważ tego czasu dotyczy najwięcej pytań: co kierowało niemiecką filozof do złożenia ofiary z samej siebie? W dyskursie naukowym istnieje wiele definicji ofiary. W swoich rozważaniach zasygnalizuję jedynie, jakie stanowisko przyjmuje etnologia, a jakie filozofia.

Etnologia określa ofiarę jako formę kultu religijnego- która jest obecna od antyku aż do współczesności w każdej kulturze. Po modlitwie jest drugą formą kultu religijnego, polegającą na składaniu darów bóstwu w intencji przebłagania za winy bądź dziękczynienia; ma na celu również zapewnienie sobie przychylności lub pomocy¹.

Inną definicję ofiary znajdziemy u J. Tischnera: „w ofierze wyraża się przeświadczenie, że człowiek jest dla kogoś. Nie żyjemy dla siebie" ${ }^{\prime \prime}$ „, Ofiara to coś więcej niż samo okrucieństwo. Ona świeci dodatkowym blaskiem i rzuca światło

1 B. Walendowska, Stownik etnologiczny. Terminy ogólne, Warszawa - Poznań 1987, s. 266.

2 J. Tischner, Filozofia dramatu, Kraków 2012, s. 229. 
na poświęcenie, które stało się wielką możliwością człowieka. Ofiara to ból i śmierć - z sensem. Sens sprawia, że ofiara wyrasta ponad okrucieństwo" ${ }^{\prime \prime}$.

\section{Dzień narodzin Edith Stein - analogia do Starego Testamentu}

Znamiennym jest, że E. Stein urodziła się w żydowskie święto Jom Kippur-Dzień Pokuty, Dzień Pojednania. Hebrajskie słowo kippur pochodzi od słowa kappara oznaczającego przebaczenie. Jest to najważniejsze święto w życiu religijnym Żydów. W tym dniu obowiązuje całkowity post; nie wolno jeść ani pić. Nie wolno również myć się lub smarować ciała olejkami. Jom Kipur twa 26 godzin, a wiąże się to z liczbą 26, która odpowiada niewypowiadanemu imieniu Boga: $J u d-H e j-W a w-J u d$. Ceremonia rozpoczyna się od modlitwy Kol Nidre, która ma na celu rozwiązanie wszelkich przysiag złożonych pod przymusem. Rytuał znany jest od ok. tysiąca lat, lecz największego znaczenia nabrał w czasach wygnania Żydów z Hiszpanii i zmuszenia ich do konwersji na chrześcijaństwo. W Księdze Kapłańskiej znajdziemy dokładny opis rytuału odprawianego w Dzień Przebłagania, rytuał ów, obecnie nie jest już praktykowany. Kapłan wchodził w świątyni do najświętszego miejsca, gdzie stawiano przed nim dwa kozły i rzucano losy. Ten, na którego padł los stawał się ofiarą za grzechy całego narodu. Na drugim koźle dokonywano rytuału przebłagania, po czym był on wypędzany na pustynię. ${ }^{4}$. Joseph Ratzinger wskazuje na zasadniczą ideę Dnia Przebłagania jako: „,krew ofiary wchłaniająca w siebie wszystkie ludzkie grzechy, dotyka samego Bóstwa i zostaje przez to oczyszczona, a w następstwie tego kontaktu czystość odzyskują również reprezentowani przez krew ludzie ${ }^{\prime \prime}$. Można tu dopatrywać się pewnej analogi-w swym życiu E. Stein przyjmie rolę „„kozła”, który stał się ofiarą za własny naród.

\section{Istota Dnia Pojednania}

Dzień Pokuty, pozwala zrozumieć własne człowieczeństwo i odnaleźć swoje miejsce w świecie. Podczas tego święta odbywa się wyznanie win, którego tekst złożony jest z dwudziestu dwóch formuł - liczba ta odpowiada ilości liter w alfabecie. Żydzi traktują to święto jako radosne, ponieważ wówczas dokonuje się oczyszczenie z win lub proszą również bliźnich o wybaczenie im grzechów. W Dzień Pojednania czytana jest Księga Jonasza, będąca pierwszą księgą biblijna, która nie mówi o karach jakie spadną na grzeszników, ale o skrusze i samooczyszczeniu. Sam prorok Jonasz jest osoba, która ucieka przed swoim przeznaczeniem, przed Bogiem i przed własnym człowieczeństwem ${ }^{6}$. Prorok wiedzie długą wędrówkę, kończącą się kryjówką w szałasie. Tam zostaje wezwany przez Boga do podjęcia posłannictwa. Jego misja religijna okazuje się być rewolucyjną- Bóg powierza mu głoszenie ideału skruchy, dzięki, której ma uleczyć miasto z nieprawości.

Widoczna jest tu kolejna analogia do losów E. Stein, która niejako również w swoim życiu ucieka przed swoim przeznaczeniem jakim jest Karmel. W swoim pamiętniku napisze o sobie: „w moich snach zawsze widziałam przed sobą świetlaną przyszłość. Śniłam o szczęściu i sławie, ponieważ byłam przekonana, że jestem stworzona do rzeczy wielkich, a zażyłe drobnomieszczańskie relacje, pośród których przyszłam na świat, bynajmniej mnie nie dotyczyły"7. Można domniemywać, że niemiecka filozof niejako od wczesnych lat młodości wyczuwa swoją misję, nie przypuszczającjaka droga ją czeka. W liście skierowanym do Gertrudy von le Fort z 1935 r. pisze: „życie ofiary prowadziłam w świecie. Teraz został mi odjęty prawie cały ciężar i w tej pełni mam wszystko, czego mi przedtem nie dostawało. Są u nas siostry- oczywiście od których Pan wymaga codziennie ofiary. I na mnie - spodziewam się przyjdzie czas bolesnego odczucia powołania do Krzyża; teraz Pan mnie traktuje jeszcze jak małe dziecko" ${ }^{\prime \prime}$.

\section{Ofiarowanie SIEBIE Za Żydów I Za Niemcy}

Od rozpoczęcia studiów na Uniwersytecie Wrocławskim, poprzez studia u Edmunda Husserla w Getyndze, pracę w Czerwonym Krzyżu na Morawach, posadę nauczycielki w Spirze aż do bram Karmelu, E. Stein nigdy nie przestaje być patriotką i żydówka, co odbija się piętnem na jej życiu. Żyjąc w cieniu dwóch wojen jest świadkiem dojścia do władzy nazistów. Jako żydówka odczuwa na sobie represje społeczne wobec narodu Izraela, tracąc posadę na uniwersytecie. Lata

\footnotetext{
3 T. Ponikło, Józef Tischner myślenie wedtug miłości. Ostatnie słowa, Kraków 2013, s. 171

4 Biblia Tysiąclecia, Księga Kapłańska, 16, 6-14, Poznań 2003.

5 J. Ratzinger, Jezus z Nazaretu, T. II , Kielce 2007, s. 50.

P. Śpiewak, Pięć ksiag Tory, Warszawa 2012, s. 242.

7 E. Stein, Dzieje pewnej żydowskiej rodziny, Kraków 2005, s 51.

8 E. Stein, Pisma, T. II, Kraków 1982, s. 246.
} 
jej życia to czas kryzysu społeczeństwa zachodniego, gdzie ateizm staje się „historyczną koniecznością".W 1933 r. jakby proroczo wyczuwa represje, które nastąpią wobec Żydów i katolików, o czym informuje w swoim liście do Papieża Piusa XI. E. Stein miała mistyczną wizję w której objawił jej się Chrystus: „rozmawiałam ze Zbawicielem i powiedziałam Mu, że wiem, iż to jego krzyż zostanie teraz włożony na naród żydowski. Większość nie rozumie tego. Ci jednak, którzy rozumieja powinni go w imieniu wszystkich chętnie na siebie wziąć. Pragnę to uczynić. Niech mi tylko wskaże, jak"10 ${ }^{\prime \prime}$ tym samym roku wstępuje do zakonu w Kolonii, gdzie oprócz modlitwy oddaje się pracy intelektualnej; ostatnim dziełem jakie tworzy jest Wiedza Krzyża, gdzie końcowy rozdział zostaje zakończony jej tragiczną śmiercią. W 1938 r. zostaje przeniesiona do holenderskiego klasztoru w Echt z powodu narastającej nagonki na ludność pochodzenia żydowskiego. Tam również zostaje aresztowana w 1942 r. przez gestapo wraz ze swoją siostrą Różaj wtedy właśnie miała wypowiedzieć znamienne słowa: „,chodź idziemy za swój naród”"11. Sporną kwestią pozostaje do dziś rzekome prawdopodobieństwo ocalenia życia poprzez ucieczkę do Szwajcarii. Podczas swojego odczytu w Krakowie w 1968 r. wspomina o tym zdarzeniu Roman Ingarden: „to Pan nie wie, to przecież była Prusaczka, ona się sama zgłosiła jak wyszedł rozkaz jak poddani niemieccy mają się poddac' ${ }^{\prime \prime 12}$. W tej postawie czyn, którego dokonała uczennica E. Husserla, przybiera wydźwięk pełen konsekwencji w swoim postępowaniu, jak i heroizmu.

\section{Testament Edyty Stein}

9.06.1939 roku siostra Teresa Benedykta od Krzyża spisuje swój testament, $\mathrm{w}$ którym pisze: „Już teraz przyjmuję z radością śmierć, którą mi Bóg przeznaczyłl, w pełnym poddaniu się Jego Najświętszej Woli. Proszę Pana, by zechciał przyjać moje życie i umieranie na swoją cześć i chwałę, we wszystkich intencjach Najświętszego Serca Jezusa i Maryi, za święty Kościół, zwłaszcza za zachowanie, uświęcenie i doskonałość naszego świętego Zakonu, szczególnie Karmelu kolońskiego i Karmelu w Echt, na zadośćuczynienie za niewiarę narodu żydowskiego, aby Pan został przyjęty przez swoich i przyszło Jego Królestwo w chwale, za uratowanie Niemiec i pokój na świecie, w końcu za moich bliskich, żyjących i zmarłych, i za wszystkich których Bóg mi dał: by żaden z nich nie zginął" ${ }^{\prime \prime 13}$.W tych słowach E. Stein przewiduje swoją śmierć i składa się sama w ofierze za życie narodu żydowskiego i Niemiec. Przyjmuje na siebie niejako grzech niewiary Żydów w Jezusa, ukazując jednak, że chrześcijaństwo jest dopełnieniem judaizmu:

„Twój lud Panie, Twego Izraela

Biorę głęboko w moje własne serce.

W ukryciu modląc się i spalając w ofierze, chce go doprowadzić do Serca Zbawiciela"14.

\section{AnAlogie:}

a) Estera - E. Stein Punktem spójnym dla Synagogi i Kościoła jest Stary Testament, gdzie w Księdze Estery, E. Stein dopatrzyła się analogii związanej ze swoją osobą: „„myślę nieustannie o Królowej Esterze, która została wzięta ze swego narodu, aby wstawić się za nim przed Królem. Jestem bardzo uboga, bezsilna, małą Esterą (...."15. Postać Królowej Estery (Gwiazdy) w swym bohaterstwie i oddaniu swemu narodowi jest niejako jej odzwierciedleniem. Udaje się ona do króla Kserksesa prosić o uchylenie się od decyzji wymordowania Żydów, pomimo zakazu przybycia na dwór królewski, co wiązało się ze złamaniem prawa ${ }^{16}$.

b) Kozioł ofiarny - E. Stein. W tym miejscu zarysowuje się analogia do kozła ofiarnego, na którego przechodzily grzechy i dlatego też musiał zostać wygnany.

c) Chrystus - E. Stein Kolejna analogia odnosi się do Jezusa, który wziął na siebie grzech świata i też został niejako wygnany; ukrzyżowanie miało miejsce poza miastem. Jan Ewangelista mówił, że: „Jezus umrze za lud (Żydzi), jednak nie tylko za lud, lecz także po to, by rozproszone dzieci Boże zgromadzić w jedno. Jezus umarł za pogan i Żydów, za całą ludzkośc' ${ }^{\prime \prime 17}$

9 Czas wiary w nietzscheańskie postulaty odrzucenia Boga i wartości.

10 H. Conrad-Matruis, Moja przyjaciótka Edyta Stein, [w:] Edyta Stein albo filozofia i krzyż, Kraków 1989, s. 9.

11 E. Stein, dz. cyt. s. 575

R. Ingarden, O badaniach filozoficznych Edith Stein, [w:] E. Stein, O zagadnieniu wczucia, Kraków 1988, s. 165

12 Tamże, s. 161

13 E. Stein, dz. cyt. s. 578

14 E. Stein, Swiattość w ciemności, Kraków 1977, s. 282.

15 E. Stein, dz. cyt. s. 358.

16 P. Śpiewak, dz. cyt. s. 102.

17 J. Ratzinger, dz. cyt., s. 150 


\section{WPEYW MYŚLI FILOZOFICZNEJ W WYBORZE ZŁOŻENIA OFIARY}

Wybór tej drogi jest motywowany:

- głębokim patriotyzmem i miłością do narodu izraelskiego;

- $\quad$ własną refleksją fenomenologiczną.

Przyjaciółka Hedwig Conrad Matrius wspomina czasy studenckie: „w kręgu fenomenologicznym użyźniona więc została gleba dla poznania transcendencji i objawień, pierwiastka boskiego i samego Boga, dla ostatecznych decyzji religijnych, dla nawróceń i konwersji. Bynajmniej nie wszyscy - jakkolwiek liczni fenomenolodzy dokonali konwersji w duchu katolickim (...). Wszyscy jednak doświadczyli jakiegoś istnienia zaświatów, których istota - podobnie jak istota tak wielu innych rzeczy - nagle im się ukazała"18. Nie sposób jest tu nie wskazać „wczucia” jako metody poznawczej. Zaznaczę tu jednak tylko filozoficzny zwrot $\mathrm{w}$ stronę religii, o którym pisze E. Stein- „mogę sama być niewierząca, a przecież rozumieć, że ktoś inny za swoją wiarę składa w ofierze wszystkie ziemskie dobra jakie posiada"19. „,Wczucie” jest doświadczeniem własnej świadomości, które w ostateczności prowadzi do relacji Ja-Bóg. Jako metoda fenomenologiczna naprowadza na Boga: „kto szuka prawdy, szuka Boga, choćby o tym nie wiedział ${ }^{20}$.Swoim życiem E. Stein daje nam również świadectwo „wczucia się" w Ukrzyżowanego.

\section{FENOMENOLOGIA I JEJ WPEYW NA MYŚL E. STEIN}

E. Stein metodą fenomenologiczną analizuje również cierpienie, w którym znajduje mistyczne wzmocnienie. Dochodzi do niego przez poznanie i pogłębianie duchowości poznającego. Najwyraźniej zagadnienie teologii mistycznej, ukazane jest w Twierdzy duchoweji Wiedzy krzyża, które są podparte lekturą pism św. Teresy z Avilla i św. Jana od Krzyża. Myśl fenomenologiczna karmelitanki pokazuje cierpienie w różnych wymiarach:

- cierpienie jako droga do Boga,

- cierpienia jako droga do doskonałości, cierpienie jako wyrzeczenie,

- cierpienie jako ogołocenie,

- cierpienie jako ofiara ${ }^{21}$.

Znamienny wpływ na postawę i myślenie E. Stein wywarli jej duchowi mistrzowie. Według świętej Teresy z Avilla, aby iść za Chrystusem należy odrzucić wszystko, czego pragnie świat, za jego przykładem zrobić z siebie ofiarę².

\section{INTERPRETACJA OFIARY}

Powracając do myśli J. Tischnera, który również jako fenomenolog rozważa idee ofiary: człowiek w swoim życiu odczuwa pewną wątpliwość, co do swojego jestestwa; czuje, że nie znajduje się w miejscu, w którym być powinien. W tych rodzących się wątpliwościach pojawia się perspektywa bycia - dla - innego. Pojęcie bycia dla innego oznacza: dać komuś coś z siebie. Łączy się ze słowem mieć, ponieważ możemy dać jedynie to co posiadamy. Posiadanie związane jest z dobrem, podobnie ofiarowanie ${ }^{23}$. „Człowiek nie może odnaleźć się w pełni inaczej, jak tylko poprzez bezinteresowny dar z siebie samego"24- czytamy w Konstytucji Duszpasterskiej Soboru Watykańskiego II. Analiza określenia bycia - dla-innego możliwa jest jedynie na płaszczyźnie agatologicznej i aksjologicznej. Ostatecznie dać oznacza uczynić z siebie ofiarę. Pojawia się pytanie, czy uczynienie z siebie ofiary to bycie przeciwko sobie? Z jednej strony tak, ale ofiarując siebie człowiek ma nadzieję odzyskania siebie ${ }^{25}$.

W tych przemyśleniach na temat ofiary J. Tischner wskazuje na myśl filozoficzną E. Levinasa. Trzonem całej filozofii tego myśliciela jest rozważanie nad odpowiedzialnością za drugiego człowieka. Z E. Stein, E. Levinasa łączy oczywiście myśl fenomenologiczna, jak i dramat Holocaustu, karmelitanka przeczuwa ten dramat i doświadcza go; żydowski filozof przeprowadza medytacje nam tymże dramatem. E. Levinas odrzuca filozofię Immanuela Kanta, Edmunda Husserla, Martina Heidegerra; twierdząc, że człowiek nie jest jedynie „monadą bez okien”. Jego myślenie wyraźnie ma na celu ukazanie ważności człowieka i odpowiedzialności za drugiego, który jest w niewoli. Podobnie u E. Stein, gdzie w centrum

\footnotetext{
18 H. Conrad- Matrius, dz. cyt., Kraków 1989, s. 5.

19 E. Stein, O zagadnieniu wczucia, Kraków 1988, s.148.

20 E. Stein, dz. cyt., s. 336.

21 A. Grzegorczyk, Wplyw myśli Edyty Stein na filozofię przełomu wiekóww, Kraków 2007, s. 24

22 Teresa z Avilla, Ksiega życia, Kraków 1987, s. 390.

23 J. Tischner, Myślenie w żywiole piękna, Kraków 2013, s. 305.

24 Konstytucja Duszpasterska o Kościele w świecie współczesnym (KDK), 24

25 J.Tischner, dz. cyt., Kraków 2013, s. 305.
} 
jej mistyki znajduje się afirmacja życia i człowieka. Odpowiedzialność za drugiego człowieka u E. Levinasa jest na pierwszym miejscu przed wyborem; nie ja wybieram odpowiedzialność - to ona wybiera mnie. Odpowiedzialność zawsze na końcu wyrazi się ofiarąa

\section{ISTOTA OFIARY E. STEIN}

Filozofia E. Levinasa idealnie opisuje czyn E. Stein. E. Levinas pisał po wydarzeniach w Oświęcimiu, ponieważ miał już świadomość tego, co się tam stało, której to nie miała niemiecka filozof, miał też dystans, którego ona mieć nie mogła, jego myśl rzuca mocne, filozoficzne światło na odpowiedzialność. Odpowiedzialność wezwała ją do oddania życia za drugiego. „Odpowiedzialność oznacza, że staję na miejscu drugiego i biorę na siebie jego ciężar- Mesjasz umiera za innych, czyli zamiast innych"27. Odpowiedzialność za drugiego człowieka wyraża się w gotowości śmierci za niego; jedynie w ten sposób pozostanę sobą w pełni. W tej myśli ukazany jest czyn E. Stein, która w swych ostatnich słowach pisze: „Gdybym nie podzieliła losu mych braci moje życie byłoby zmarnowane"28. Ofiara, którą z samej siebie złożyła karmelitanka, nie jest jedynie postawą odwagi i konsekwencji swoich decyzji i wiary. Jej szlachetny czyn możemy nazwać mistyczną ofiarą Holokaustu. O wartości danego czynu pisze Władysław Stróżewski: „Szlachetność jakiegoś czynu jest wielka nie tylko jako wartość w nim zrealizowana, lecz jako pewnego rodzaju droga, uświadamiająca nam czym jest szlachetność w ogóle: podobnie jak bohaterstwo żołnierza na polu bitwy pozwala nam zrozumieć samą istotę bohaterstwa, a spotkanie z człowiekiem świętym - świętość »ssamą w sobie «"29. Podczas modlitw świadomie prosi Boga o nałożenie na siebie „krzyża” za swój naród. W synach i córkach Izraela dopatruje się niewinnej ofiary jaką stał się Chrystus przyjmując krzyż. Jej postać wpisuje się w teologię Auschwitz; swoim postępowaniem woła do całego świata chrześcijańskiego: kim jesteśmy po tym co zdarzyło się w Oświęcimiu? Kończąc swoje rozważania powołam się na wspomnianego wcześniej J. Tischnera, który opisuje czyn heroiczny: „,Człowiek ma w sobie ogromne pokłady heroizmu, jeżeli tylko heroizm służy nadziei. Wówczas człowiek widzi sens największej ofiary. Rozwiązania heroiczne są trudne dlatego, że proste, a prostych rzeczy człowiek często nie zauważa. Kto nie ma Sprawy, dla której żyje, bardzo boi się umrzeć. Świadomość sprawy porządkuje lęki" ${ }^{\prime \prime 30}$.

\section{Bibliografia}

\section{Teksty źródłowe}

[1] Pismo Święte Starego i Nowego Testamentu [Biblia Tysiaclecia], A. Jankowski (red.), zespół biblistów polskich (thum.), Poznań 2008.

[2] Sobór watykański II- konstytucje, dekrety, deklaracje, M. Przybył (red.), Poznań 2002.

\section{Książki/czasopisma}

[3] Conrad - Matrius H, Znak - Idee, Kraków 1989

[4] Grzegorczyk A., Wphtyw myśli Edyty Stein na filozofię przetomu wieków, Kraków 2007.

[5] Ponikło T, Józef Tischner, Mýślenie wedlug mitości. Ostatnie stowa, Kraków 2013.

[6] Ratzinger J., Jezus z Nazaretu, T. II, Kielce 2007.

[7] Stein E, Pisma, T. II, Kraków 1982

[8] Stein E., Dzieje perunej żydowskiej rodziny, Kraków 2005.

[9] Stein E., O zagadnieniu wczucia, Kraków 1988.

[10] Stein E., Śzwiattość w ciemności, Kraków 1977.

[11] Stróżewski W., W kręgu wartósci, Kraków 1992.

[12] Śpiewak P., Pię́́ Ksiag Tory, Warszawa 2013.

[13] Teresa z Avilla, Ksiega życia, Kraków 1987.

[14] Tischner J., Filozofia dramatu, Kraków 2012.

[15] Tischner J., Mýlenie w żywiole piękna, Kraków 2013.

[16] Walendowska B., Stownik etnologiczny. Terminy ogólne, Warszawa - Poznań 1987.

\footnotetext{
26 Tamże, s. 309

27 Tamże, s.308.

28 E. Stein, dz. cyt., s. 282.

29 W. Stróżewski, W kręgu wartości, Kraków 1992, s. 61.

30 T. Ponikło, dz. cyt., s. 165
}

OGRODY NAUK I SZTUK NR 2014 (4) 